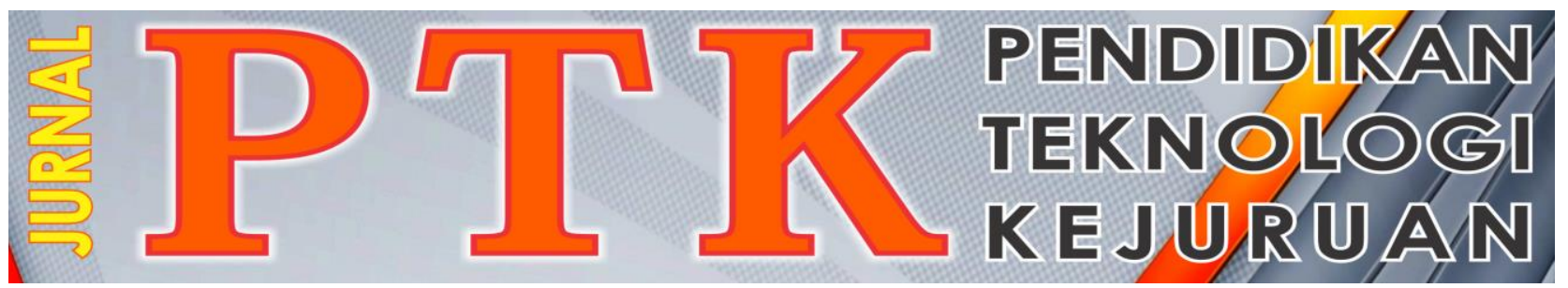

Vol. 3, No. 2 Mei 2020

P-ISSN: 2621-3273

E-ISSN: 2621-1548

\title{
THE EFFECT OF LEARNING OUTCOMES ON SUBJECT OF CREATIVE PRODUCT AND ENTREPRENEURSHIP, FAMILY SUPPORT TO ENTREPRENEURIAL INTEREST IN STUDENTS OF FASHION MANAGEMENT SMKN 6 PADANG
}

\author{
Vina Oktaviani ${ }^{1}$ and Asmar Yulastri ${ }^{2}$ \\ ${ }^{1.2}$ Technology and Vocational Education, Faculty of Engineering, Universitas Negeri Padang. \\ * Corresponding author, e-mail: voktaviann114@gmail.com*
}

\begin{abstract}
This research aims to show the effect of learning outcomes on subject of creative product and entrepreneurship, family support to entrepreneurial interest in students of Fashion Management SMKN 6 Padang. This research used quantitative research method with a correlational approach. The population of this research was all students of class XII of the Fashion Management SMKN 6 Padang with total of 122 students with the sample was 92 students which was taken on proportional random sampling. Data collection technique used a research questionnaire. The questionnaire try out was tested on 30 students of the population who were not included in the sample, then conducted a validity and reliability test. Testing of the data analysis requirement and hypotheses with the normality test, linearity test, multicollinearity test and regression analysis. The result of the analysis obtained the learning outcomes of creative product and entrepreneurship $\left(X_{I}\right)$ had an effect on Entrepreneurial Interest $(Y)$, with a significance value of $0.007\left\langle 0.05, F_{\text {calculate }}\right\rangle F_{\text {table }}(10.753>2.000)$ and an effect contribution of $53,1 \%$. Family support $\left(X_{2}\right)$ had an effect on Entrepreneurial Interest $(Y)$, with a significance value of $\left.0,000<0.05, F_{\text {calculate }}\right\rangle F_{\text {table }}(10.385\rangle$ $2.000)$ and effect contribution of 64.5\%. Learning Outcomes on Subject for Creative Product and Entrepreneurship $\left(X_{1}\right)$, Family Support $\left(X_{2}\right)$ had a positive and significant effect respectively on Entrepreneurial Interest $(Y)$ students of the Fashion Management SMKN 6 Padang, with a significance value of $0.000<0.05$ and $F c_{\text {alculate }}>F_{\text {table }}(42,662>$ 4.04) with an effect contribution of $62.7 \%$.
\end{abstract}

Keywords: Learning Outcomes on Subjects of Creative Product and Entrepreneurship, Family Support, Entrepreneurial Interest.

\section{INTRODUCTION}

Vocational High Schools endeavor to provide students with the knowledges and skills that is needed in the world of work. Vocational High School students are also provided with entrepreneurship education that engrafting entrepreneurial values, developing an entrepreneurial spirit that is creative, innovative, and sportive as well as give birth of entrepreneurs from Vocational High School students. One of the schools that provides entrepreneurship education is SMKN 6 Padang with subjects in Creative Product and Entrepreneurship. Creative Product and Entrepreneurship is compulsory subject for students in class XI and XII, especially students majoring in fashion management. Subject emphasizes the creative product of the creativity process to produce something original and meaningful. Creativity and innovation are the essence of entrepreneurship. Creativity is seen as the ability to develop ideas and be able to see opportunities. Innovation in entrepreneurship is the ability to apply creative solutions to opportunities to improve business performance (Setiawati, et al, 2018).

Based on interview with Creative Product and Entrepreneurship teacher at SMKN 6 Padang. Creative Product and Entrepreneurship can foster interest in entrepreneurship according to students' personalities. Learning consists of theory and practice. In theory, the teacher provides entrepreneurial knowledge, briefing as well as motivation that builds students' interest in entrepreneurship. In practice, students are required 
to be able to create work that has economic value as well as is able to sell the product. When viewed from the condition of students, there are still many who do not dare to become entrepreneurs because of economic conditions that are classified as middle to lower, students have lack confidence in their abilities and expertise, even though students have creativity and innovation in creating product.

Data of alumnus at SMKN 6 Padang, students who are entrepreneurs are still low can be seen in Table 1 below:

Table 1. Data of Alumnus at SMKN 6 Padang

\begin{tabular}{|l|l|l|}
\hline \multirow{2}{*}{ Type of Work } & \multicolumn{2}{|c|}{ Year } \\
\cline { 2 - 3 } & $2016 / 2017$ & $2017 / 2018$ \\
\hline Entrepreneurship & 23 Students & 47 Students \\
\hline Public University & 62 Students & 35 Students \\
\hline Private University & 83 Students & 98 Students \\
\hline $\begin{array}{l}\text { Work According to the } \\
\text { Major }\end{array}$ & 75 Students & 67 Students \\
\hline $\begin{array}{l}\text { Work Not According to } \\
\text { the Major }\end{array}$ & 60 Students & 45 Students \\
\hline Unregistered & 27 Students & 21 Students \\
\hline Total & 330 Students & 313 Students \\
\hline
\end{tabular}

Creative Product and Entrepreneurship learning provides understanding of material based on creative industry. The existence of entrepreneurship learning in Creative Product and Entrepreneurship is expected to increase student interest in entrepreneurship. Interest is feeling like and being interested in something without anyone asking, influencing as well as later paying more attention to a particular activity (Slameto, 2013). In increasing the entrepreneurial interest there is factor that can influence such as learning outcomes. Entrepreneurial interest can be influenced by students' learning outcomes, the higher the learning outcomes, the higher the entrepreneurial interest in student (Salwa, et al, 2017). Students' entrepreneurial interest can be seen through the learning outcomes obtained while participating in learning at school. Learning outcomes are abilities that the students have after receiving a learning experience. Learning outcomes include understanding concepts, students' attitudes and skills (Sudjana, 2011).

Another factor supporting the entrepreneurial interest is family. Entrepreneurial interest and mindset about entrepreneurship can be formed for someone whose scope of entrepreneurial family. The family is the main education that is received by children. Parents will influence the development, behavior as well as influence in choosing of the work later. Encouragement and family support is the initial capital that can strengthen the mentality of being an entrepreneur (Khairani, 2013). The family can be a conducive environment to train and sharpen the entrepreneurial character of children (Chomzana, 2014).

This study aims to show the effect of learning outcomes on subject of creative product and entrepreneurship on the entrepreneurial interest of students of the Fashion Management SMKN 6 Padang. Showing the effect of family support on the entrepreneurial interest of students of the Fashion Management SMKN 6 Padang. Showing the effect of learning outcomes on creative product and entrepreneurship, family support for entrepreneurial interest of students of the Fashion Management SMKN 6 Padang.

\section{METHOD}

\section{A. Research Type}

This research used quantitative research method with a correlational approach. The researcher chose to use correlational research to show the effect between the independent variable and the dependent variable related to the research that will be researched so as to produce conclusion that give clear description of the research object.

\section{B. Place and Time of Research}

The place of research was at SMKN 6 Padang, which is located on Suliki Street Number 1 Jati Baru, East Padang District, Padang City, West Sumatra. Research time will be conducted on January, $2^{\text {nd }} 2020$ - Februry $2^{\text {nd }}, 2020$.

\section{Population and Sample}

The research population was all students of class XII of Fashion Management SMKN 6 Padang with the total of 122 students. The research sample was taken using Proportional Random Sampling technique. A sample of 92 students in class XII of Fashion Management SMKN 6 Padang.

\section{Research Instrument}

The research instrument is a measuring instrument to measure and collect data from the variables that is researched (Sugiyono, 2017). The instrument used in this research was a research questionnaire for family support variables $\left(\mathrm{X}_{2}\right)$ and entrepreneurial interest (Y). Variable of learning outcomes for Creative Product and Entrepreneurship subjects $\left(\mathrm{X}_{1}\right)$ were taken from score of the final exam. 
Table 2. Research Instrument

\begin{tabular}{|c|c|c|c|}
\hline Variable & Indicator & $\begin{array}{l}\text { No. } \\
\text { Item }\end{array}$ & Source \\
\hline \multirow[t]{5}{*}{$\mathrm{Y}$} & $\begin{array}{l}\text { Have a commitment } \\
\text { and desire for } \\
\text { entrepreneurship }\end{array}$ & $1-8$ & \multirow[t]{2}{*}{$\begin{array}{l}\text { Suryana } \\
(2013: 14)\end{array}$} \\
\hline & Act creatively & $9-16$ & \\
\hline & $\begin{array}{l}\text { Have the ability and } \\
\text { willingness to } \\
\text { entrepreneurship }\end{array}$ & $17-28$ & \multirow[t]{3}{*}{$\begin{array}{l}\text { Suryana } \\
(2013: 108)\end{array}$} \\
\hline & $\begin{array}{l}\text { Have strong } \\
\text { determination and } \\
\text { hard work }\end{array}$ & $29-40$ & \\
\hline & $\begin{array}{l}\text { Able to see chances } \\
\text { and opportunities }\end{array}$ & $41-50$ & \\
\hline $\mathrm{X}_{1}$ & The cognitive value & \multicolumn{2}{|c|}{$\begin{array}{l}\text { Learning outcomes } \\
\text { on subjects of } \\
\text { creativeproduct and } \\
\text { entrepreneurship }\end{array}$} \\
\hline \multirow[t]{4}{*}{$\mathrm{X}_{2}$} & Emotional support & $1-13$ & \multirow{4}{*}{$\begin{array}{c}\text { Periera } \\
(2017: 73)\end{array}$} \\
\hline & Assessment support & $14-23$ & \\
\hline & $\begin{array}{l}\text { Instrumental } \\
\text { support }\end{array}$ & $24-29$ & \\
\hline & Information support & $30-35$ & \\
\hline
\end{tabular}

\section{E. Try Out Test of Instrument}

A try out test was conducted to find out whether the instruments used, tested its level of validity and reliability.

\section{1) Test of the Instrument Validity}

Validity is the accuracy of an instrument in measuring to be examined. An instrument can be said to be valid if it can be used to obtain data and measure data validity (Sugiyono, 2013). Testing instrument used the Product Moment Correlation technique. If the correlation of each factor is positive and the magnitude of 0.30 above then the factor is a strong construct (Yulastri, et al, 2017),

\section{a. Test of Variable Validity $Y$}

Table 3. Validity of Entrepreneurial Interest Variable

\begin{tabular}{|l|l|c|c|}
\hline Variable & Indicator & $\begin{array}{l}\text { Number } \\
\text { of invalid } \\
\text { item }\end{array}$ & $\begin{array}{l}\text { Total of } \\
\text { Valid } \\
\text { Item }\end{array}$ \\
\hline $\begin{array}{l}\text { Entrepre } \\
\text { neurial } \\
\begin{array}{l}\text { Interest } \\
\text { (Y) }\end{array}\end{array}$ & $\begin{array}{l}\text { Have a } \\
\text { commitment and } \\
\text { desire for } \\
\text { entrepreneurship }\end{array}$ & 1,2 & 6 \\
\cline { 2 - 4 } & Act creatively & 14 & 7 \\
\cline { 2 - 4 } & $\begin{array}{l}\text { Have the ability } \\
\text { and willingness to } \\
\text { entrepreneurship }\end{array}$ & 27 & 11 \\
\cline { 2 - 4 } & $\begin{array}{l}\text { Have strong } \\
\text { determination and } \\
\text { hard work }\end{array}$ & 33,36 & 10 \\
\cline { 2 - 4 } & $\begin{array}{l}\text { Able to see } \\
\text { chances and } \\
\text { opportunities }\end{array}$ & 41,42 & 8 \\
\cline { 2 - 4 } & \multicolumn{2}{|c|}{ Total of Valid Item } & 42 \\
\hline
\end{tabular}

Based on Table 3 above, the statement of item 1 obtained item correlation $\left(\mathrm{r}_{\text {calculate }}\right)<\left(\mathrm{r}_{\text {table }}\right)$ that was 0.253 . Item 2 obtained item correlation ( $\left.\mathrm{r}_{\text {calculate }}\right)$ $<\left(\mathrm{r}_{\text {table }}\right)$ that was 0.289 . Item 14 obtained item correlation $\left(\mathrm{r}_{\text {calculate }}\right)<\left(\mathrm{r}_{\text {table }}\right)$ that was equal to 0.282 . Item 27 obtained item correlation $\left(\mathrm{r}_{\text {calculate }}\right)<\left(\mathrm{r}_{\text {table }}\right)$ that was 0.297 . Item 33 obtained item correlation $\left(\mathrm{r}_{\text {calculate }}\right)<\left(\mathrm{r}_{\text {table }}\right)$ that was 0.239 . Item 36 obtained item correlation $\left(\mathrm{r}_{\text {calculate }}\right)<\left(\mathrm{r}_{\text {table }}\right)$ that was a total of 0.236 . Item 41 obtained item correlation ( $\mathrm{r}_{\text {calculate }}$ ) $<\left(\mathrm{r}_{\text {table }}\right)$ that was -0.056 and item 42 obtained item correlation $\left(\mathrm{r}_{\text {calculate }}\right)<\left(\mathrm{r}_{\text {table }}\right)$ that was 0.253 .

\section{b. Validity Test of Variable $X_{2}$}

Table 4. Validity Test of Family Support Variable

\begin{tabular}{|l|l|c|c|}
\hline Variable & Indicator & $\begin{array}{l}\text { Number } \\
\text { of invalid } \\
\text { item }\end{array}$ & $\begin{array}{l}\text { Total of } \\
\text { Valid } \\
\text { Item }\end{array}$ \\
\hline $\begin{array}{l}\text { Family } \\
\text { Support }\left(\mathrm{X}_{2}\right)\end{array}$ & $\begin{array}{l}\text { Emotional } \\
\text { support }\end{array}$ & 8,11 & 11 \\
\cline { 2 - 4 } & $\begin{array}{l}\text { Assessment } \\
\text { support }\end{array}$ & - & 10 \\
\cline { 2 - 4 } & $\begin{array}{l}\text { Instrumental } \\
\text { support }\end{array}$ & - & 6 \\
\cline { 2 - 4 } & $\begin{array}{l}\text { Information } \\
\text { support }\end{array}$ & - & 6 \\
\hline \multicolumn{2}{|l}{ Total of Valid Item } & 33 \\
\hline
\end{tabular}

Based on Table 4 above, in item 8 statement obtained item correlation $\left(\mathrm{r}_{\text {calculate }}\right)<\left(\mathrm{r}_{\text {table }}\right)$ that was 0.035 and item 11 statement obtained item correlation $\left(\mathrm{r}_{\text {calculate }}\right)<\left(\mathrm{r}_{\text {table }}\right)$ that was 0.237 .

\section{2) Test of Instrument Reliability}

Reliability refers to the level of reliability of something, reliable means to be trusted and reliable.

Table 5. Cronbach's Alpha value

\begin{tabular}{|l|l|l|}
\hline No. & Cronbach's Alpha Value & Relationship Level \\
\hline 1. & $0,80 \leq \alpha \leq 1,00$ & Very Strong \\
\hline 2. & $0,60 \leq \alpha<0,80$ & Strong \\
\hline 3. & $0,40 \leq \alpha<0,60$ & Sufficient \\
\hline 4. & $0,20 \leq \alpha<0,40$ & Low \\
\hline 5. & $0,00 \leq \alpha<0,20$ & Very Low \\
\hline
\end{tabular}

Table 6. Test of Variable Reliability

\begin{tabular}{|l|c|c|}
\hline \multicolumn{1}{|c|}{ Variable } & $\begin{array}{c}\text { Cronbach's } \\
\text { Alpha } \\
\text { Coefficient }\end{array}$ & $\begin{array}{c}\text { Relationship } \\
\text { Level }\end{array}$ \\
\hline $\begin{array}{l}\text { Entrepreneurial Interest } \\
(\mathrm{Y})\end{array}$ & 0,940 & Very Strong \\
\hline Family Support $\left(\mathrm{X}_{2}\right)$ & 0.934 & Very Strong \\
\hline
\end{tabular}

Based on Table 6, the variable instrument reliability of Entrepreneurial Interest (Y) obtained a Cronbach's Alpha Coefficient value of 0.940. Family Support Variable $\left(\mathrm{X}_{2}\right)$ obtained Cronbach's Alpha Coefficient of 0.934 . 


\section{F.Test of Data Analysis Requirement}

\section{1) Normality Test}

Testing for normality used the KolmogorovSmir-nov test (K-S test). If the significance or probability value $<0.05$ then the data is said to have an abnormal distribution. If the significance or probability value $>0.05$ then the data is said to be normally distributed.

\section{2) Linearity Test}

Linearity test to prove whether each independent variable $(\mathrm{X})$ has a linear relationship or not with the dependent variable (Y). If the significance value $<0.05$, the variables $\mathrm{X}$ and $\mathrm{Y}$ can be stated nonlinear. If the significance value $>0.05$, the variables $\mathrm{X}$ and $\mathrm{Y}$ can be stated linear.

\section{3) Multicollinearity Test}

Multicollinearity test is performed for multiple regression analysis with two or more independent variables so that it can find out whether the variable occurs multicollinearity or not. If the VIF value $\geq 10$ and the Tolerance Value $\leq 0.10$, there will be symptom of Multicollinearity. If VIF $\leq 10$ and the Tolerance Value $\geq 0.10$, the model is free from Multicollinearity and can be used in a research.

\section{Hypothesis}

Hypothesis testing used multiple regression analysis technique. If $\mathrm{Sig}>\alpha(0.05)$ then $\mathrm{H}_{\mathrm{o}}$ is accepted, whereas if $\mathrm{Sig}<\alpha(0.05)$ then $\mathrm{H}_{\mathrm{o}}$ is rejected.

\section{RESULT AND DISCUSSION}

\section{A. Test of Data Analysis Requirement}

1) Normality Test

Table 7. Normality Test $Y, X_{1}$, dan $X_{2}$

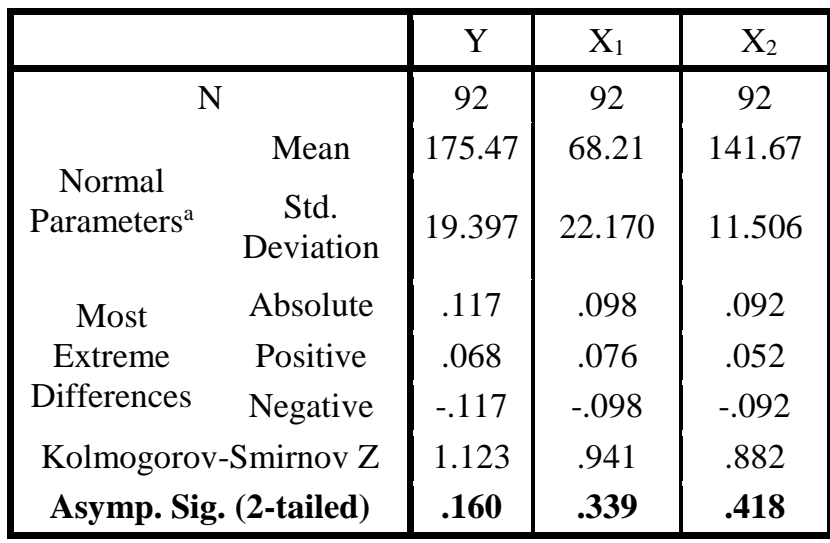

Table 7 above, the Asymp.Sig. (2-tailed) value was greater than 0.05 . Entrepreneurial Interest $(\mathrm{Y})$ obtained a significance value of $0.160>0.05$ so that the data were normally distributed. Learning Outcomes on Subjects for Creative Product and Entrepreneurship $\left(\mathrm{X}_{1}\right)$ obtained a significance value of $0.339>0.05$ so that the data were normally distributed. Family Support $\left(\mathrm{X}_{2}\right)$ obtained a significance value of $0.418>0.05$ so that the data were normally distributed.

\section{2) Linearity Test}

Table 8. Linearity Test of $X_{\mathrm{i}}$ Variable with $Y$

ANOVA Table

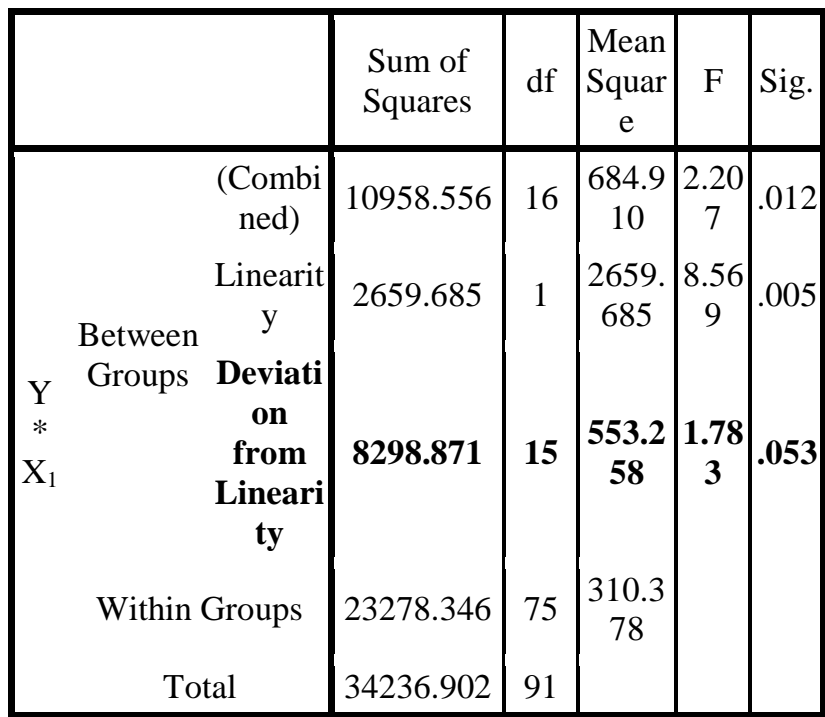

Table 8 showed the significance value of the Deviation From Linearity obtained by $0.053>0.05$ so that Creative Product and Entrepreneurship data $\left(\mathrm{X}_{1}\right)$ with Entrepreneurial Interest $(\mathrm{Y})$ was stated linear.

Table 9. Linearity Test of Variables X2 with Y ANOVA Table

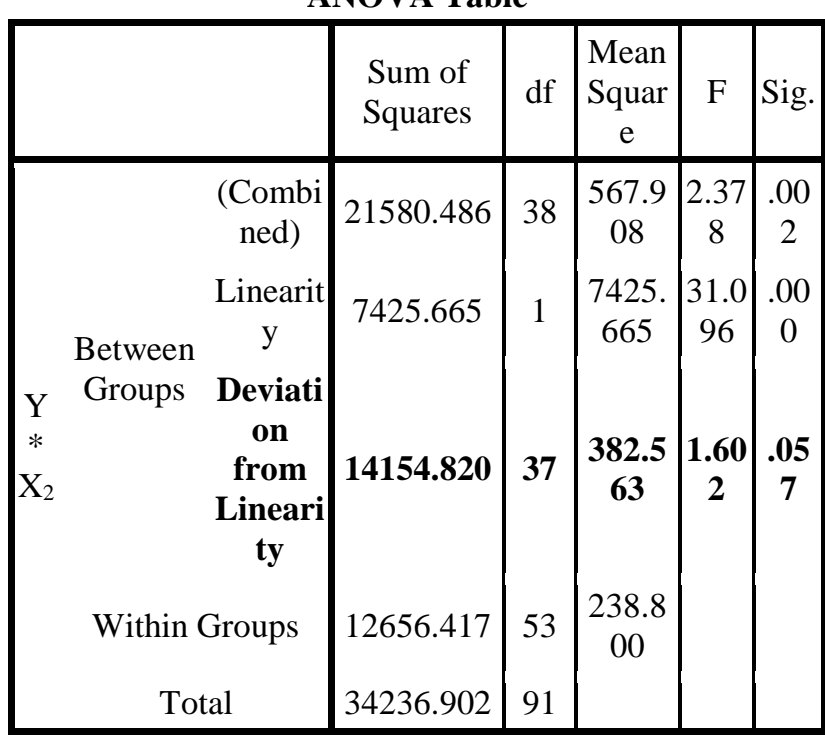

Table 9 showed that the significance value of the Deviation From Linearity obtained was $0.057>0.05$ so that the Family Support $\left(\mathrm{X}_{2}\right)$ data with Entrepreneurial Interest (Y) was stated linear. 
3) Multicollinearity Test

Multicollinearity test was conducted to determine whether the regression model was found a correlation between independent variable.

Table 10. Multicollinearity Test

\begin{tabular}{|c|c|c|c|c|c|c|c|}
\hline \multicolumn{8}{|c|}{ Coefficients $^{\mathrm{a}}$} \\
\hline \multirow[t]{2}{*}{ Model } & \multicolumn{2}{|c|}{$\begin{array}{l}\text { Unstandardiz } \\
\text { ed } \\
\text { Coefficients }\end{array}$} & \multirow{2}{*}{\begin{tabular}{|c}
$\begin{array}{c}\text { Standar } \\
\text { dized } \\
\text { Coeffic } \\
\text { ients }\end{array}$ \\
Beta
\end{tabular}} & \multirow[t]{2}{*}{$\mathrm{T}$} & \multirow[t]{2}{*}{ Sig. } & \multicolumn{2}{|c|}{$\begin{array}{c}\text { Collinearity } \\
\text { Statistics }\end{array}$} \\
\hline & B & $\begin{array}{l}\text { Std. } \\
\text { Error }\end{array}$ & & & & $\begin{array}{l}\text { Toler } \\
\text { ance }\end{array}$ & VIF \\
\hline $\begin{array}{l}\text { (Co } \\
\text { nsta } \\
\text { nt) }\end{array}$ & $\begin{array}{c}16.48 \\
8\end{array}$ & $\begin{array}{c}18.12 \\
4\end{array}$ & & .910 & .365 & & \\
\hline $\mathrm{X}_{1}$ & .095 & .064 & .109 & $\begin{array}{c}1.49 \\
5\end{array}$ & .139 & .897 & 1.114 \\
\hline $\mathrm{X}_{2}$ & .139 & .131 & .082 & $\begin{array}{c}1.05 \\
7\end{array}$ & .293 & .787 & 1.271 \\
\hline
\end{tabular}

a. Dependent Variable: Y

Table 10 above showed that the variables $X_{1}$ and $\mathrm{X} 2$ had a VIF value $\leq 10$ and a Tolerance Value $\geq 0.10$. The overall VIF value of the independent variable was $\left(\mathrm{X}_{1}=1,114 ; \mathrm{X}_{2}=1,271\right) \leq 10$. Tolerance Value The overall value of the independent variable $\left(\mathrm{X}_{1}=0,897 ; \mathrm{X}_{2}=0,787\right) \geq$ 0,10 so that there was no multicollinearity disturbance.

\section{4) Hypothesis Test}

\section{a) The First Hypothesis Test}

Variable Hypothesis testing of Learning Outcomes on Subjects for Creative Product and Entrepreneurship $\left(\mathrm{X}_{1}\right)$ on the variable of Entrepreneurial Interest (Y).

Table 11. Hypothesis Test $\mathrm{X}_{1}$ with $\mathrm{Y}$

\begin{tabular}{|c|c|c|c|c|c|c|c|}
\hline & \multicolumn{2}{|c|}{ R-R2 Value } & \multicolumn{2}{|c|}{ F Value } & \multirow[b]{2}{*}{$\begin{array}{l}\mathrm{Si} \\
\mathrm{g} .\end{array}$} & \multirow{2}{*}{$\begin{array}{l}\text { Reg } \\
\text { ress } \\
\text { ion } \\
\text { Coe } \\
\text { ffici } \\
\text { ent }\end{array}$} & \multirow[b]{2}{*}{$\begin{array}{l}\text { Kon } \\
\text { st. }\end{array}$} \\
\hline & $\begin{array}{l}\mathrm{R}_{\mathrm{X} 1} \\
\mathrm{Y}\end{array}$ & $\mathrm{R}^{2} \mathrm{X} 1 \mathrm{Y}$ & $\begin{array}{l}\mathrm{F}_{\text {calcula }} \\
\text { te }\end{array}$ & $\mathrm{F}_{\text {table }}$ & & & \\
\hline $\begin{array}{l}\mathrm{X}_{1} \\
-\mathrm{Y}\end{array}$ & $\begin{array}{l}0,72 \\
9\end{array}$ & 0,531 & $\begin{array}{l}10.75 \\
3\end{array}$ & 2.000 & $\begin{array}{l}0 . \\
00 \\
7\end{array}$ & $\begin{array}{l}0.74 \\
4\end{array}$ & $\begin{array}{l}58.8 \\
35\end{array}$ \\
\hline
\end{tabular}

Based on Table 11, the regression equation obtained was $\mathrm{Y}=58.835+0.744 \mathrm{X}$ with a significance value of $0.007<0.05$ and $\mathrm{F}_{\text {calculate }}>\mathrm{F}_{\text {table }}$ $(10.753>2.000)$ so that Ho was rejected. The first hypothesis was accepted, which means there was a positive and significant effect of learning outcomes on entrepreneurial interest. b) The Second Hypothesis Test

Hypothesis test of Family Support variable $\left(\mathrm{X}_{2}\right)$ on the variable of Entrepreneurial Interest (Y).

Table 12. Hypothesis X2 Test with Y Variable

\begin{tabular}{|c|c|c|c|c|c|c|c|}
\hline & \multicolumn{2}{|c|}{ R-R2 Value } & \multicolumn{2}{|c|}{ F Value } & \multirow{2}{*}{$\begin{array}{l}\mathrm{Si} \\
\mathrm{g} .\end{array}$} & \multirow[b]{2}{*}{$\begin{array}{c}\text { Reg } \\
\text { ress } \\
\text { ion } \\
\text { Coe } \\
\text { ffici } \\
\text { ent }\end{array}$} & \multirow{2}{*}{$\begin{array}{c}\text { Kon } \\
\text { st. }\end{array}$} \\
\hline & $\begin{array}{l}\mathrm{R}_{\mathrm{X} 1} \\
\mathrm{Y}\end{array}$ & $\mathrm{R}^{2} \mathrm{X} 1 \mathrm{Y}$ & $\begin{array}{l}\mathrm{F}_{\text {calcula }} \\
\text { te }\end{array}$ & $\mathrm{F}_{\text {table }}$ & & & \\
\hline $\begin{array}{l}\mathrm{X}_{1} \\
-\mathrm{Y}\end{array}$ & $\begin{array}{l}0.74 \\
4\end{array}$ & 0.645 & $\begin{array}{l}10.38 \\
5\end{array}$ & 2.000 & $\begin{array}{l}0, \\
00 \\
0\end{array}$ & $\begin{array}{l}0.93 \\
9\end{array}$ & $\begin{array}{l}40.9 \\
89\end{array}$ \\
\hline
\end{tabular}

Based on Table 12, the regression equation was obtained $\mathrm{Y}=40.989+0.939 \mathrm{X}$ with a significance value of $0,000<0.05$ and $\mathrm{F}_{\text {calculate }}>\mathrm{F}_{\text {table }}(10.385>$ 2.000 ) so that Ho was rejected. The second hypothesis was accepted, which means there was a positive and significant effect of family support on entrepreneurial interest.

\section{c) The Third Hypothesis Test}

The third hypothesis testing can be used multiple regression model. Hypothesis testing variable of Learning Outcomes on Subjects for Creative Product and Entrepreneurship $\left(\mathrm{X}_{1}\right)$, Family Support $\left(\mathrm{X}_{2}\right)$ respectively on Entrepreneurial Interest (Y).

Table 13. Test of Hypothesis $\mathrm{X}_{1}, \mathrm{X}_{2}$, on $\mathrm{Y}$

\begin{tabular}{|c|c|c|c|c|c|c|}
\hline \multirow[b]{2}{*}{$\begin{array}{c}\text { Coef. } \\
\text { Reg }\end{array}$} & \multicolumn{2}{|c|}{ R-R2 Value } & \multicolumn{2}{|c|}{ F Value } & \multirow[b]{2}{*}{ Sig } & \multirow[b]{2}{*}{$\begin{array}{c}\text { Konst } \\
.\end{array}$} \\
\hline & $\begin{array}{c}\mathrm{RY}(1 \\
.2)\end{array}$ & $\begin{array}{c}\mathrm{R}^{2} \mathrm{Y}( \\
1.2)\end{array}$ & Fcal & $\begin{array}{c}\text { Fta } \\
\text { b }\end{array}$ & & \\
\hline 0.139 & \multirow{2}{*}{0.792} & \multirow{2}{*}{0.627} & \multirow{2}{*}{42.662} & \multirow{2}{*}{4.04} & \multirow{2}{*}{$\begin{array}{c}0,00 \\
0\end{array}$} & \multirow{2}{*}{$\begin{array}{c}36.48 \\
8\end{array}$} \\
\hline 0.095 & & & & & & \\
\hline
\end{tabular}

Based on Table 13, the regression equation obtained was $\mathrm{Y}=36.488+0.139 \mathrm{X}_{1}+0.095 \mathrm{X}_{2}$ with a significance value of $0,000<0.05$ and $F_{\text {calculate }}>$ $\mathrm{F}_{\text {table }}(42.662>4.04)$ so that $\mathrm{H}_{\mathrm{o}}$ was rejected. There was a positive and significant effect on the learning outcomes of creative product and entrepreneurial, and family support for entrepreneurial interest.

\section{B.Discussion}

1) The Effect of Learning Outcomes on Subjects of Creative Product and Entrepreneurship $\left(\mathrm{X}_{1}\right)$ on Entrepreneurial Interest (Y) Students of the Fashion Management SMKN 6 Padang.

The result of research obtained that there was a positive and significant effect on learning outcomes on subject of creative products and entrepreneurship on the entrepreneurial interest students of the Fashion Management SMKN 6 Padang. Obtaining a significance value of $0.007<0.05$ and $F_{\text {calculate }}>F_{\text {table }}$ (10.753> 2,000) so that Ho was rejected. The coefficient value was positive 0.74 showed that the 
learning outcomes on subject of creative products and entrepreneurship on entrepreneurial interest had a directly proportional relationship, which means the higher the learning outcomes, the higher the entrepreneurial interest. The correlation coefficient (R) obtained 0.729 and the coefficient of determination (R2) obtained 0.531 , which means the contribution of the effect of learning outcomes on entrepreneurial interest by $53.1 \%$ in the sufficient category.

The results of this research was in line with Salwa's research entitled "Entrepreneurial Interest Viewed from Student Learning Outcomes". The research result obtained positive and significant effect of learning outcomes on entrepreneurial interest and the higher the learning outcomes, the higher the interest in student entrepreneurship. Obtaining a significance value of $0,000<0.05$ and $\mathrm{F}_{\text {calculate }}>\mathrm{F}_{\text {table }}(29.577>4.10)$ with an effect of $35.5 \%$.

2) The Effect of Family Support $\left(X_{2}\right)$ on Entrepreneurial Interest (Y) students of Fashion Management SMKN 6 Padang.

The result of research obtained that there was a positive and significant effect of family support on the entrepreneurial interest students of the Fashion Management SMKN 6 Padang. Obtaining a significance value of $0,000<0.05$ and $F_{\text {calculate }}>F_{\text {table }}$ $(4.605>2,000)$ so that Ho was rejected. The coefficient value was positive 0.939 indicated that family support had a directly proportional relationship. The correlation coefficient $(\mathrm{R})$ obtained 0.744 and the coefficient of determination (R2) obtained 0.645 , which means the contribution of the effect of family support on entrepreneurial interest by $64.5 \%$ in the strong category.

The results of this research was in line with the research by Periera, et al. entitled "The Effect of Parental Support on Children's Interest in Entrepreneurship". The result obtained that there was a effect of family support on children's interest in entrepreneurship. Obtaining a positive coefficient of 0.715 indicated that family support had a directly proportional relationship. The coefficient of determination (R2) was $45.87 \%$, which means the contribution of family support to entrepreneurial interest was $45.87 \%$.

3) The Effect of Learning Outcomes on Subjects of Creative Product and Entrepreneurship $\left(\mathrm{X}_{1}\right)$, Family Support $\left(\mathrm{X}_{2}\right)$ respectively on Entrepreneurial Interest (Y) students of the Fashion Management SMKN 6 Padang.

The research result obtained that there was a positive and significant effect on the learning outcomes on subject of creative product and entrepreneurship, and family support respectively on entrepreneurial interest. Obtaining a significance value of $0,000<0.05$ and $F_{\text {calculate }}>F_{\text {table }}(42.662>$ 4.04) so that Ho was rejected. The correlation coefficient (R) obtained 0.792 and the coefficient of determination (R2) obtained 0.627 , which means the contribution of the effect of learning outcomes on subject of creative product and entrepreneurship, and family support respectively on entrepreneurial interest by $62.7 \%$ in the strong category.

\section{CONCLUSION}

Based on the result of the research it can be concluded:

1. Learning Outcomes on Subjects for Creative Product and Entrepreneurship $\left(\mathrm{X}_{1}\right)$ had a positive and significant effect on Entrepreneurial Interest (Y) students of the Fashion Management SMKN 6 Padang. The effect that was obtained including in a sufficient effect of $53,1 \%$.

2. Family Support $\left(\mathrm{X}_{2}\right)$ had a positive and significant effect on Entrepreneurial Interest (Y) students of the Fashion Management SMKN 6 Padang. The effect that was obtained including in a strong effect of $64,5 \%$.

3. Learning Outcomes on Subjects for Creative Product and Entrepreneurship $\left(\mathrm{X}_{1}\right)$, and Family Support $\left(\mathrm{X}_{2}\right)$ had a positive and significant effect respectively on Entrepreneurial Interest (Y) students of the Fashion Management SMKN 6 Padang. The effect that was obtained including in a strong effect of $62,7 \%$.

\section{REFERENCES}

A. Yulastri, H. Hidayat, Ganefri, S. Islami, and F. Edya, (2017) "Developing an Entrepreneurship Module by Using Product-Based Learning Approach in Vocational Education," Int. J. Environ. Sci. Educ., vol. 12, no. 5, pp. 1097-1109.

Chomzana K.M dan Siti Hamidah. (2014). Pengaruh SelfEfficacy, Lingkungan Keluarga, dan Lingkungan Sekolah terhadap Minat Berwirausaha Siswa SMK Jasa Boga. (Online), Volume 4, Nomor 1, (https://journal.uny.ac.id/index.php/jpv/article/vie w/2545, diakses 27 Juli 2019).

Khairani, M. (2013) Psikologi Pembelajaran. Yogyakarta: Aswara Persindo.

Salwa, dkk. (2017). Minat Berwirausaha Ditinjau Dari Hasil Belajar Peserta Didik. (Online), Volume 1 Nomor 1.

Setiawati, Tati dan Karpin. (2018) Modul Produk Kreatif dan Kewirausahaan. Pendidikan Profesi Guru (PPG). Jakarta: Direktorat Jendral Pembelajaran dan Kemahasiswaan Kementerian Riset Teknologi dan Pendidikan Tinggi.

Slameto. (2013). Belajar dan Faktor yang Mempengaruhinya. Jakarta: Rineka Cipta. 
Sudjana, Nana. (2011). Penilaian Hasil Proses Belajar Mengajar. Bandung: PT. Remaja Rosdikarya.

Sugiyono. (2013). Metode Penelitian Manajemen. Bandung: Alfabeta.

Sugiyono. (2017). Metode Penelitian: Kuantitatif, Kualitatif dan $R \& D$. Bandung: Alfabeta.

\section{Author's Biography}

Vina Oktaviani was born in Serang on October 21st, 1995. In 2017 she obtained her Bachelor of Education degree in the Department of Family Welfare, Study Program of Family Welfare Education Concentration in Fashion Management in Tourism and Hospitality of State University of Padang. In 2020 she obtained his Master of Education degree in the Department of Technology and Vocational Education, Postgraduate Program, Faculty of Engineering, State University of Padang.

Asmar Yulastri was born in Kuranji on June 19th, 1964. In 1990, she completed her undergraduate education at State University of Padang. In 1998, she completed her master education at State University of Yogyakarta. In 2015, she completed his postgraduate education at Kebangsaan University of Malaysia. She is currently a permanent lecturer in the Tourism and Hospitality Faculty of State University of Padang. 